\title{
Breed and stocking rate effects on Chihuahuan Desert cat- tle production
}

\author{
JOHN A. WINDER, CALVIN C. BAILEY, MILTON THOMAS, AND JERRY HOLECHEK
}

Authors are associate professor, senior research assistant, assistant professor, and professor, Dept. of Animal and Range Sciences, New Mexico State Univ., Las Cruces, N.M. 88003. J. Winder is presently livestock specialist, Samuel Roberts Noble Foundation, P.O. Box 2180, Ardmore, Okla. 73402.

\begin{abstract}
Productivity of Barzona, Brangus, and Beefmaster cattle was evaluated on conservatively $(n=2)\left(40\right.$ ha $\left.\mathrm{AU}^{-1}\right)$ and moderately (28.5 ha $\left.\mathrm{AU}^{-1}\right)$ stocked pastures $(n=2)$ in the Chihuahuan Desert of south-central New Mexico. Equivalent numbers of suckled, first-calf heifers of each breed $(n=31)$ weighing $333 \pm 11 \mathrm{~kg}$ were randomly assigned to the study pastures in the spring of 1992. Pastures were grazed continuously and herd productivity data were collected from 1992-1994. In late August 1994, all pastures were destocked due to onset of severe drought. No effect of breed $(\mathbf{P}>0.10)$ was detected in the analyses, so data were pooled across breeds and compared between the stocking rates. Calf crop percentages $(1993,1994)$ were higher in conservative than moderate stocked pastures $(82$ vs $62 \%$, respectively, $P<0.01)$. Financial analyses standardized to a hypothetical medium size $(8,094$ ha) New Mexico Chihuahuan Desert cattle range showed net returns per ha did not differ $(\mathbf{P}>\mathbf{0 . 1 0})$ between stocking rates. However, the main effect of year and stocking rate $x$ year interaction were significant $(P<0.05)$. These analyses suggest that the drought in 1994 lowered returns per ha compared to 1993 when precipitation was near average and that conservative stocking may present less financial risk than moderate stocking when drought occurs. These data are consistent with other studies from arid and semi-arid rangelands demonstrating that conservative stocking can give financial returns from cattle production equal to or greater than those from moderate stocking.
\end{abstract}

Key Words: rangeland, ruminants, grazing management, economics

Chihuahuan Desert rangelands are an important source of forage for beef cattle production in New Mexico (New Mexico Department of Agriculture 1994). Beefmaster, Barzona, and Brangus cattle have become prevalent in the southwestern United States. However, reports are limited regarding the relative merits of these breeds in the Chihuahuan Desert. Past research in southcentral New Mexico has shown that Brangus and Brangus crossbred cows are more productive than Hereford cattle (Winder et al. 1992). Furthermore, recent research has shown that grazing behavior and diet selection may differ among breeds (Blanton 1995, Winder et al. 1996).

This research was supported by the New Mexico Agr. Exp. Sta., Las Cruces, N.M. 88003 and was part of project 1-5-27474.

Manuscript accepted 24 Apr. 1999.
Resúmen

La productividad de ganado Barzona, Brangus y Beefmaster fue evaluada en potreros $(n=2)$ sujetos a capacidad de carga animal conservadora $\left(40\right.$ ha $\mathrm{AU}^{-1}$ y capacidad de carga animal moderada $(n=2)\left(28.5 \mathrm{AU}^{-1}\right)$ en la región centro-sur de Nuevo Mexico. Números equivalentes de vaquillas primerizas de cada raza $(n=31)$ amamantando $y$ con peso de $333 \pm 11 \mathrm{~kg}$, fueron asignadas al azar en los potreros del area de estudio en la primavera de 1992. Los potreros estuvieron bajo pastoreo continuo y la productividad de los hatos fue recabada durante 1992-1994. En agosto de 1994, debido a la sequía, se dejaron descansar los potreros. Ningún efecto raza $(P<0.10)$ fué detectado en el análisis, por lo tanto los datos fueron analizados conjuntando todas las razas y comparando éste número al efecto carga animal. El porcentaje de natalidad (1993-1994) fué $20 \%$ mas alto bajo condiciones de pastoreo conservador. Los números indican $82 \%$ y $62 \%$ de natalidad bajo pastoreo conservador y moderado respectivamente $(\mathrm{P}<0.10)$. El peso al momento del destete por vaquilla por año fué también mas alto bajo condiciones de pastoreo conservador $(P<\mathbf{0 . 1 0})$. Los análisis financieros ajustados hipoteticamente a un rancho de tamaño medio ( 8094 ha) en el centro-sur de Nuevo México, indicaron que la ganancia económica neta por hectárea no fué diferente $(P>0.10)$ entre los dos tipos de carga animal. Sin embargo, el efecto principal de la interacción capacidad de carga-año fué significante $(P<0.05)$. Estos resultados sugieren que la sequía de 1994 redujo la ganacia económica por hectárea comparada con el año 1993 cuando la precipitación pluvial estuvo cerca del promedio normal. Asimismo, sugieren que el pastoreo conservador pudiera representar un menor riesgo financiero que el pastoreo moderado sobre todo al momento de la aparición de la sequía. Estos datos son consistentes con otros estudios en zonas áridas y semiáridas, que demuestran que el pastoreo conservador puede proporcionar la misma ganancia económica que el pastoreo moderado. Sin embargo, la diferencia estriba en mejores pastizales y tazas de natalidad mas altas bajo pastoreo conservador.

Stocking rate is also a major factor affecting cattle productivity and financial returns from ranching in semidesert rangelands (Martin 1975, Holechek 1992). It has been hypothesized that conservative stocking involving about $35 \%$ use of key forage species will result in enhanced animal performance and financial returns compared to moderate stocking (40-50\% use of forage; (Martin 1975, Holechek 1992). The primary objectives of this experiment were to evaluate the effect of breed (Brangus, Barzona, and 
Beefmaster), stocking rate and breed $\mathrm{x}$ stocking rate interaction on cow productivity under Chihuahuan Desert conditions in southcentral New Mexico. A secondary objective was to evaluate the implications of our findings on Chihuahuan Desert ranching profitability.

\section{Materials and Methods}

\section{Study Area}

Four study pastures were located on the Chihuahuan Desert Rangeland Research Center (CDRRC) were used to evaluate the effect of breed and stocking rate on Chihuahuan Desert cattle production. The ranch is $37 \mathrm{~km}$ north of Las Cruces, N.M. in Dona Ana County. The ranch is in the southern portion of the Jornada del Muerto Plains between the San Andres Mountains to the east and the Rio Grande Valley to the west $\left(\sim 32.3^{\circ}\right.$ Latitude and $106^{\circ}$ Longitude). Elevation varies from 1,188 to $1,371 \mathrm{~m}$ with level or gently rolling hills.

Soils on the study pastures are mainly light sandy loams underlain by calcium carbonate hardpan (caliche) at depths varying from a few centimeters to $1 \mathrm{~m}$ or more (Valentine 1970). They are classified as fine loamy, mixed, thermic, typic haplargids and are in the Simona-Cruces associations (SCS 1980). In areas where the ground cover is sparse, sandy dunes had formed around the invading mesquite plants (Wood 1969). However on most of the study area, the soil profile is relatively well preserved and stable.

The climate on the CDRRC is typical of the Chihuahuan Desert. The ranch is arid with an average frost-free period of 200 days. The only permanent water sources are the wells and pipelines provided for livestock. Temperatures are high in summer, with a mean maximum of $36^{\circ} \mathrm{C}$ during June, and a mean maximum of $13^{\circ} \mathrm{C}$ during January (Pieper and Herbel 1982). Temperature differences are substantial between day and night. Solar radiation is generally greatest in June and lowest in December. Winds are strongest in the spring and cause severe erosion problems and water stress on the plants.

The annual precipitation is bi-modal. Summer precipitation is generated from the Gulf of Mexico and is characterized by localized convectional storms of high intensity but low frequency. Winter precipitation (December-February) comes from the Pacific Ocean. Storms in the winter are relatively gentle and evenly distributed. The mean annual precipitation is 230 $\mathrm{mm}$ with $52 \%$ of the annual rainfall occur-

Table 1. Average monthly precipitation $(\mathrm{mm})$ on the Chihuahuan Desert Rangeland Research Center in southcentral New Mexico.

\begin{tabular}{|c|c|c|c|c|c|c|}
\hline Month & 1990 & 1991 & 1992 & 1993 & 1994 & $\begin{array}{c}\text { Long term average } \\
(1930-1996)\end{array}$ \\
\hline January & 5 & 12 & 38 & 37 & 8 & 13 \\
\hline February & 10 & 13 & 4 & 14 & 3 & 10 \\
\hline March & 11 & 15 & 9 & 1 & 4 & 7 \\
\hline April & 13 & 0 & 29 & 1 & 4 & 6 \\
\hline May & 10 & 4 & 89 & 7 & 13 & 9 \\
\hline June & 0 & 4 & 11 & 20 & 6 & 13 \\
\hline July & 75 & 74 & 13 & 69 & 25 & 42 \\
\hline August & 49 & 74 & 105 & 62 & 16 & 46 \\
\hline September & 56 & 53 & 6 & 5 & 9 & 36 \\
\hline October & 5 & 0 & 23 & 9 & 23 & 22 \\
\hline November & 19 & 22 & 14 & 14 & 35 & 18 \\
\hline December & 18 & 114 & 46 & 14 & 35 & 18 \\
\hline Total & 271 & 385 & 386 & 253 & 178 & 235 \\
\hline
\end{tabular}

ring during the summer peak (Pieper and Herbel 1982).

Rain gauges are located throughout the CDRRC and extensive records were available. The total annual precipitation for the CDRRC in 1991, 1992, and 1993 was above average (Table 1). In the 1994 growing season precipitation was near the all time low ( $41 \%$ of the mean). All pastures were destocked in late August of 1994 due to lack of forage growth.

\section{Vegetation}

Primary grass species on our study pastures include black grama (Bouteloua eri opoda Torr.), dropseed (Sporobolus sp.), three-awns (Aristida sp.), bush muhly (Muhlenbergia porteri Kunth.), fluffgrass (Erioneuron pulchellum Tateoka), and tobosa (Hilaria mutica Buckley). The most commonly encountered shrub species is honey mesquite (Prosopis glan dulosa Torr.). It dominates the overstory and has been increasing over the past 100 years (Pieper and Herbel 1982). Other shrubs commonly found are snakeweed (Gutierrizea sarothrae Pursh), soaptree yucca (Yucca elata av.), creosote (Larrea tridentata [Pursh] Nutt.), and fourwing saltbush (Atriplex canescens [Pursh] Nutt). Leatherweed croton (Croton pottsii Lam.) is the primary forb occurring on the CDRRC and is an important food for livestock and pronghorn.

During 1991, four pastures with similar soils (sandy loams), topography (flat), and size were delineated and fenced. These include Pasture 15 (1,267 ha), Pasture 4 (974 ha), Pasture 14 (932 ha), and Pasture 1 (1,219 ha). The 4 pastures were adjacent to each other and the spatial ordering of the pastures from west to east was 15,14 , 1 , and 4. Proportions of late, mid, and early seral communities in each pasture based on the Dyksterhuis (1949) approach are given in Table 2. Pastures 15 and 4 were stocked to obtain a utilization level of about $30-35 \%$ of key forage species while pastures 14 and 1 were selected to be stocked to obtain a utilization level of 40-45\%. The Holechek (1988) procedure was used in setting pasture stocking rates. The reliability of this procedure on Chihuahuan Desert rangelands has been established (Holechek and Pieper 1992). A more detailed discussion of the experimental pastures is provided by Nelson (1996).

In June 1993, five transects $1.6 \mathrm{~km}$ in length were systematically placed in each pasture to monitor herbage production and plant foliar cover. Foliar cover data were collected in autumn 1993 and 1994 and were reported by Nelson (1996) and Nelson et al. (1997). Standing crop data were collected by clipping to ground level five, $0.5 \mathrm{~m}^{2}$ quadrats on each transect on each sampling date. Periodically (spring, summer, and fall) grazing intensity on the 4 pastures was evaluated by estimation of percent utilization through ocular reconnaissance and measurement of key perennial grass stubble heights as outlined by Anderson and Currier (1973). This information is reported by Nelson (1996).

\section{Experimental Animals}

The pastures were stocked with equal proportions of 3 breeds of cattle $(n=31$ heifers per breed averaging $333 \pm 11 \mathrm{~kg}$ ) at the initiation of the study in spring of 1992. The 3 cattle breeds used in this study were Barzona, Brangus, and Beefmaster. Barzona cattle have a red color and are a combination of Hereford, Angus, Santa Gertrudis, and Africander 
Table 2. Percentages of open grassland, mixed grass-shrub, and shrubland on pastures 15, 4, 14, and 11.

\begin{tabular}{rccc}
\hline \hline Pasture & $\begin{array}{c}\text { Open grassland } \\
\text { late seral condition }\end{array}$ & $\begin{array}{c}\text { Mixed grass-shrub } \\
\text { mid seral condition }\end{array}$ & $\begin{array}{c}\text { Shrubland } \\
\text { early seral condition }\end{array}$ \\
\hline & $-\cdots$ & 35 & 6 \\
15 & 59 & 51 & 0 \\
4 & 49 & 21 & 24 \\
14 & 55 & 51 & 9 \\
1 & 40 & $\%$ & \\
\hline
\end{tabular}

Determinations were made by Dr. Dee Galt, a certified range consultant.

${ }^{2}$ This category included small areas that were near or at climax ecological condition.

breeds (Ensminger 1976). Brangus cattle include 5/8 Angus + 3/8 Brahman and are characterized by black color, moderate size, and moderate milk production. Beefmaster include 1/4 Hereford, 1/4 Shorthorn, and 1/2 Brahman (Ensminger 1976).

In 1990, the institutional care and use committee of New Mexico State University approved the purchase of 50 Barzona, 49 Beefmaster, and 50 Brangus heifer calves from ranches in New Mexico and Arizona (IACUC protocol \#95). Heifers weighed $229 \pm 5 \mathrm{~kg}$ on arrival at the CDRRC in the autumn of 1990. After an initial receiving program which included vaccinations for brucellosis, leptospirosis, infectious bovine rhinotracheitis, and bovine viral diarrhea, the heifers were placed on native range and supplemented with $1-1.5 \mathrm{~kg}$ of a $20 \%$ crude protein range cube per day during winter and spring 1991. The heifers gained $0.3 \pm .03$ $\mathrm{kg} /$ day and weighed $261 \pm 6.4 \mathrm{~kg}$ at the start of the breeding season (1 May). During the breeding season, heifers were exposed to Hereford bulls for 120 days (May through August) during the first (1991) and subsequent breeding seasons (1992, 1993, 1994). In November, 1991, heifers were tested for pregnancy by rectal palpation; all non-pregnant heifers were culled. Heifers were then calved on native range in the spring of 1992 and then those that supported a calf were blocked by breed and weight and randomized within blocks to either conservative $\left(40 \mathrm{ha}^{-1}\right)$ or moderately (28.5 ha $\left.\mathrm{AU}^{-1}\right)$ stocked pastures at the beginning of the breeding season in 1992 (i.e., thus, there was a 100\% calf crop for each pasture in 1992). Animal unit (AU) was defined as a 1,000 pound $(454 \mathrm{~kg})$ cow without or with a calf $\leq 6$ months of age (Society for Range Management 1989).

No culling was done in subsequent years after assignment of cows to pastures. Cows remained in their assigned pastures for the duration of the study. They were supplied mineral and salt free-choice, but received no protein or energy supplementation. Three Hereford bulls were placed in each pasture during the May-August period of 1992, 1993, and 1994. All bulls were determined to be fertile with breeding soundness exams before being placed with the herds for breeding. Calves were weighed and tagged at birth. Cows were weighed 3 times per year (precalving: January and February; prebreeding: May-June; weaning, October). Calves were weighed at weaning and these weights were adjusted according to the Beef Improvement Federation Guidelines 205-day adjusted weaning weight to account for differences in weaning weight due to age of calf and cow (BIF 1996). In late August of 1994, grazing was terminated in all 4 pastures due to the onset of severe drought.

\section{Economic Analysis}

Effects of stocking rate on Chihuahuan Desert ranching profitability was determined using the procedures of Holechek (1992, 1994). Under these procedures ranching costs and returns are standardized to ranch budgets published annually for different New Mexico grazing regions (Torell and Hawkes 1995, Torell et al. 1998). These budgets are derived for small, medium, and large size ranches based on rancher interviews. The standardized production units were an 8,094 hectare medium sized ranch carrying either 200 animal units (conservatively stocked) or 284 animal units (moderately stocked). In these calculations, actual health care and supplemental feeding costs at the CDRRC were used, rather than those for the average Chihuahuan Desert ranch.

\section{Statistical Analyses}

Differences in cattle productivity among breeds and stocking rates were analyzed with a repeated measures model using the General Linear Model (GLM) procedures of SAS (1988). In this analysis individual cattle were used as replicates which maximizes capability to detect treatment differences. Also, treatment means were adjust- ed for unequal sub-class numbers using least squares procedures. A factorial analysis of variance was also used to compare cattle productivity measures and financial returns among stocking rates (conservative, moderate) and years (1993 and 1994). Pastures 15 and 4 were used as replicates for the conservatively stocked treatment, and pasture 14 and 1 were replicates for the moderately stocked treatment. The LSD test was used to separate means at the 5\% significance level (Steel and Torrie 1980).

\section{Results and Discussion}

\section{Vegetation Cover and Standing Crop}

Previously, we reported that percentage foliage cover of black grama, total grasses, and total vegetation was higher in conservatively than moderately stocked pastures (Nelson et al. 1997). In the current study, standing crops $\left(\mathrm{kg} \mathrm{ha}^{-1}\right)$ of black grama, dropseeds, threeawns, fluffgrass, and total grasses were higher $(\mathrm{P}<0.05)$ in conservatively than moderately stocked pastures by autumn 1993 (Year 2 of the study; Table $3)$. A stocking rate $x$ year interaction $(\mathrm{P}<0.05)$ was detected for the variable total grasses. This is explained by lower growing season precipitation in 1994 compared to 1993 (Table 1). Black grama was the primary forage plant found in conservatively stocked pastures based on both foliar cover and standing crop. In moderately stocked pastures, threeawns were the most prevalent forage plant. Threeawns were the second most observed forage plants in conservatively stocked pastures. Dropseeds were the third most prevalent plant in the conservatively stocked pastures, but second in prevalence in moderately stocked pastures (Nelson et al. 1997 and Table 3).

Foliar cover and forage standing crop data indicated there were some vegetation composition differences between conservatively and moderately stocked pastures. Autumn vegetation surveys and periodic grazing intensity surveys showed lower forage availability in moderately than conservatively stocked pastures in 1993 and 1994 with sizeable areas dominated by black grama existing in all 4 pasturees (Table 2 and 3, Nelson 1996, Nelson et al. 1997). We interpret the data to indicate that forage availability as influenced by stocking rate and the annual precipitation were the primary factors that influenced cattle productivity. However, we do acknowledge that plant species composi- 
Table 3. Standing forage crop $\left(\mathrm{kg} \mathrm{ha}^{-1}\right)$ on conservatively (CS) and moderately (MS) stocked pastures on the Chihuahuan Desert Rangeland Research Center in autumn 1993 and autumn 1994.

\begin{tabular}{|c|c|c|c|c|}
\hline \multirow[b]{2}{*}{ Plant species } & \multicolumn{2}{|c|}{1993} & \multicolumn{2}{|c|}{1994} \\
\hline & CS & MS & CS & MS \\
\hline & \multicolumn{4}{|c|}{$\ldots \ldots \ldots \ldots \ldots\left(\mathrm{kg} \mathrm{ha}^{-1}\right) \ldots \ldots \ldots \ldots \ldots$} \\
\hline \multicolumn{5}{|l|}{ Grasses } \\
\hline Bouteloua eriopoda & $272^{\mathrm{a}}$ & $57^{\mathrm{b}}$ & $367^{\mathrm{a}}$ & $30^{\mathrm{b}}$ \\
\hline Sporobolus spp. & $140^{\mathrm{a}}$ & $68^{\mathrm{b}}$ & $29^{\mathrm{b}}$ & $15^{\mathrm{b}}$ \\
\hline Aristida spp. & $179^{\mathrm{a}}$ & $224^{\mathrm{a}}$ & $81^{\mathrm{b}}$ & $179^{\mathrm{a}}$ \\
\hline Erioneuron pulchellum & 11 & 5 & 2 & 10 \\
\hline Other grasses & trace & 2 & trace & 47 \\
\hline Total grassesd & $592^{\mathrm{a}}$ & $356^{\mathrm{bc}}$ & $479^{\mathrm{b}}$ & $281^{\mathrm{c}}$ \\
\hline \multicolumn{5}{|l|}{ Forbs } \\
\hline Croton pottsii & 21 & 6 & 4 & 3 \\
\hline Other forbs & 1 & 6 & trace & trace \\
\hline Total forbs & 22 & 12 & 4 & 3 \\
\hline \multicolumn{5}{|l|}{ Shrubs } \\
\hline Gutierrezia sarothrae & $325^{\mathrm{a}}$ & $162^{\mathrm{b}}$ & $133^{\mathrm{b}}$ & $187^{\mathrm{b}}$ \\
\hline Total vegetation & $939^{\mathrm{a}}$ & $530^{\mathrm{b}}$ & $616^{\mathrm{b}}$ & $471^{\mathrm{b}}$ \\
\hline
\end{tabular}

${ }^{\mathrm{abc}}$ Means within rows with different superscripts differ at $\mathrm{P}<0.05$. tion differences among conservatively and moderately stocked pastures could have exerted minor influences on the results.

\section{Breed Effects}

Beefmaster cows produced 20 and 28 more kilograms of calf at weaning annually than Barzona and Brangus cows, respectively $(\mathrm{P}<0.02$, Table 4$)$. However, no differences $(\mathrm{P}>0.16)$ were observed for 205-day adjusted weaning weights, pregnancy rates among yearling heifers, or overall weaning percentages. Breed of cow $\mathrm{x}$ stocking rate interactions were nonsignificant $(\mathrm{P}>0.10)$. Based on these similar productivity measures, all 3 cattle breeds appeared to be similarly adapted to Chihuahuan Desert rangelands.

In 1991 and 1992, forage selection and nutritional status of Barzona, Beefmaster, and Brangus cattle were evaluated on the CDRRC (Becerra et al. 1998). This study showed little difference in diet botanical composition and fecal $\mathrm{N}$ and $\mathrm{P}$ concentraBrangus cattle. Although breed x season interactions did occur for a few dietbotanical composition components, their practical importance was doubtful due to low magnitude and lack of consistency among seasons. Individual animal behavior and physiology rather than diet botanical composition and quality would appear to explain productivity differences that may exist among the cattle breeds studied. Results from Becerra et al. (1998) were inconsistent with reports of Herbel and Nelson (1966) and Winder et al. (1996) that indicated cattle breeds do have differences in diet selection that are of practical tions among Barzona, Beefinaster, and
Production differences among breeds may have been observed if the study had been repeated on rangeland lower in ecological condition with more shrubs present. In summer, Barzona cattle consumed more honey mesquite than Brangus and Beefmaster cattle indicating they may rangelands with a high mesquite component (Becerra et al. 1998). Nevertheless, breed differences were not detected in the study. Therefore, the data were pooled across breeds to evaluate stocking rate effects on cattle productivity.

\section{Stocking Rate Effects}

The analyses used to compare conservative to moderate stocking rates revealed that conservative stocking yielded higher calf crop percentages than moderate stocking $(\mathrm{P}<0.05$, Table 4$)$. A stocking rate $\mathrm{x}$ year interaction $(\mathrm{P}<0.05)$ was also detected in calf crop percentage with the analyses used to evaluate hypothetical financial differences between conservative and moderate stocked pastures (Table 5). Cows grazing conservatively stocked pastures produced more actual and 205-day adjusted weaning weight per cow per year than cows grazing moderately stocked pastures (Table 4). However, differences in actual calf weaning weights were not detected $(\mathrm{P}>0.10)$ with the analyses used to evaluate financial differences between the conservative and moderate stocking rate (Table 5).

Our data are consistent with a wide range of studies (26) reviewed by Vallentine (1994) and Holechek et al. (1999) which indicate that calf crop perhave some potential to improve use of studies involving biologically dive breeds may not have been present in the current study population.

Table 4. Effect of breed and stocking rate on annual cow productivity on the Chihuahuan Desert Rangeland Research Center for the years 1992, 1993, and 1994 period. Breed of cow x stocking rate interactions were not detected $(P>0.10)$ in the study, so data were pooled across breeds and evaluated based upon stocking rate.

\begin{tabular}{|c|c|c|c|c|c|c|c|}
\hline \multirow[b]{3}{*}{ Trait } & \multicolumn{4}{|c|}{ Breed Effects } & \multirow{2}{*}{\multicolumn{3}{|c|}{ Brangus ${ }^{c}$}} \\
\hline & \multicolumn{2}{|c|}{ Barzona $^{c}$} & \multicolumn{2}{|c|}{ Beefmaster ${ }^{c}$} & & & \\
\hline & $\mathrm{LSM}^{\mathrm{a}}$ & $\mathrm{SE}^{\mathrm{b}}$ & $\mathrm{LSM}^{\mathrm{a}}$ & $S E^{b}$ & $\mathrm{LSM}^{\mathrm{a}}$ & $\mathrm{SE}^{\mathrm{b}}$ & $\mathrm{OSL}^{\mathrm{c}}$ \\
\hline Weaning wt/cow/yr (kg) & 159 & 6 & 179 & 7 & 151 & 7 & .02 \\
\hline $205-\mathrm{d} w \mathrm{t} / \mathrm{cow} / \mathrm{yr}(\mathrm{kg})$ & 161 & 7 & 180 & 8 & 162 & 7 & .16 \\
\hline$\%$ pregnant as yearlings & 78 & 7 & 63 & 7 & 69 & 7 & .30 \\
\hline$\%$ weaned $^{\mathrm{d}}$ & 84 & 3 & 86 & 4 & 82 & 4 & .74 \\
\hline \multicolumn{8}{|c|}{ Stocking Rate Effects } \\
\hline Trait & & $\mathrm{LSM}^{\mathrm{a}}$ & $\mathrm{SE}^{\mathrm{b}}$ & & $\mathrm{LSM}^{\mathrm{a}}$ & $\mathrm{SE}^{\mathrm{b}}$ & $\mathrm{OSL}^{\mathrm{c}}$ \\
\hline Actual weaning wt/cow/yr (kg) & & 173 & 5 & & 153 & 5 & .01 \\
\hline $205-\mathrm{d} w \mathrm{t} / \mathrm{cow} / \mathrm{yr}(\mathrm{kg})$ & & 180 & 6 & & 156 & 6 & .01 \\
\hline 205-d wt/ha/yr (kg) & & 4.4 & & & 5.5 & & \\
\hline Calf crop $\%$ & & 89 & 3 & & 79 & 3 & .02 \\
\hline
\end{tabular}

${ }^{\mathrm{a}}$ Least square means.

${ }^{\mathrm{b}}$ Standard errors.

${ }^{c}$ Observed significance level.

${ }^{\mathrm{d}}$ Percentage weaned after all non-pregnant yearling heifers were culled in fall 1991. 
Table 5. Cattle production and financial characteristics for conservative (CS) and moderate stocked (MS) pastures on the Chihuahuan Desert Rangeland Research Center in 1993 and 1994 standardized to a medium sized 8094 ha ranch (see Torell and Hawkes 1995 and Torell et al. 1998).

\begin{tabular}{lcccc}
\hline \hline & \multicolumn{2}{c}{1993} & \multicolumn{2}{c}{1994} \\
Characteristic & $\mathrm{CS}^{\mathrm{c}}$ & $\mathrm{MS}^{\mathrm{d}}$ & $\mathrm{CS}^{\mathrm{c}}$ & $\mathrm{MS}^{\mathrm{d}}$ \\
\hline Ranch size, ha & 8094 & 8094 & 8094 & 8094 \\
Number of animal units & 200 & 284 & 200 & 284 \\
Total precipitation, cm & 253 & 253 & 178 & 178 \\
Growing season precipitation, cm & 163 & 163 & 69 & 69 \\
Percent use of forage & $30-35$ & $40-45$ & $35-40$ & $45-50$ \\
Calf crop, $\%$, & $75^{\mathrm{a}}$ & $38^{\mathrm{b}}$ & $90^{\mathrm{a}}$ & $87^{\mathrm{a}}$ \\
Calf weaning weight, $\mathrm{kg}^{1}$ & $217^{\mathrm{a}}$ & $217^{\mathrm{a}}$ & $130^{\mathrm{b}}$ & $137^{\mathrm{b}}$ \\
Fall cow weight, $\mathrm{kg}^{1,3}$ & $445^{\mathrm{a}}$ & $495^{\mathrm{a}}$ & $395^{\mathrm{b}}$ & $392^{\mathrm{b}}$ \\
Gross income, $\$$ & 60,214 & 50,265 & 42,475 & 61,098 \\
Fixed costs, $\$$ & 18,042 & 18,042 & 22,102 & 22,102 \\
Variable cost, $\$$ & 19,452 & 27,622 & 22,352 & 31,740 \\
Total costs, $\$$ & 37,494 & 45,664 & 44,454 & 53,842 \\
Net income, $\$$ & $22,720^{\mathrm{a}}$ & $4,602^{\mathrm{b}}$ & $-1,978^{\mathrm{b}}$ & $7,256^{\mathrm{a}}, \mathrm{b}$ \\
Net income, $\$ / \mathrm{AU}^{2}$ & $114^{\mathrm{a}}$ & $16^{\mathrm{b}}$ & $-9^{\mathrm{b}}$ & $26 \mathrm{a},{ }^{\mathrm{b}}$ \\
Net income, $\$ / \mathrm{ha}^{2,3}$ & $2.80^{\mathrm{a}}$ & $0.57^{\mathrm{b}}$ & $-0.24^{\mathrm{b}}$ & $0.90^{\mathrm{a}, \mathrm{b}}$ \\
\hline
\end{tabular}

${ }^{1}$ Actual values are used for all cattle production characteristics.

${ }^{\mathrm{a}, \mathrm{b}}$ Means within rows with different superscripts are significantly different $(\mathrm{P}<0.05)$

centages are highly sensitive to stocking rate. Across these studies, calf crop percentages averaged $7 \%$ higher under moderate than heavy stocking rates. However, light stocking only gave $3 \%$ higher calf crops than moderate stocking. Most of these studies involved humid or semi-arid environments and in some cases cattle received protein and (or) energy supplements. Based on our results, stocking rate effects on calf crop percentages appear to be accentuated in desert, compared with semi-arid and humid environments. Data on autumn foliar cover and standing forage crop (Table 3; Nelson et al., 1997) provide evidence to suggest that cattle in conservatively stocked pastures had access to about $50 \%$ more forage than moderately stocked pastures. Although nutritional status of cattle in the current study was not evaluated, the higher standing crop of forage in conservatively stocked pastures potentially reduced energy expenditure in foraging activity and possibly improved diet quality and intake, compared with moderately stocked pastures. The work of Vavra et al. (1973) supports this statement.

Calf crop percentage in 1993 was greater in conservative than moderate stocked pastures, but in 1994, these crops appeared to be equal [year by stocking rate effect $(\mathrm{P}<0.05)$; Table 5]. Our explanation of this result is that cows in moderately stocked pastures not producing calves in 1993 probably recovered sufficient body condition to breed and produce calves in 1994. With no supplemental feeding, these data provide evidence to suggest that moderate stocking could result in depressed calf crops every 2-3 years. These results

\section{Economic Analyses}

Hypothetical net returns per ha from conservatively and moderately stocked pastures $(1993,1994)$ did not differ $(\mathrm{P}>$ 0.10 , Table 5). However, the main effect of year and stocking rate $\mathrm{x}$ year interaction were significant $(\mathrm{P}<0.05)$. Financial returns were severely depressed during drought in 1994. This was due to reduced calf weaning weights and lower cattle prices in 1994. The stocking rate $\mathrm{x}$ year interaction was caused by the depressed calf crop on moderately grazed pastures in 1993 as previously discussed.

Financial returns in Table 5 do not reflect 2 important costs. These include the opportunity cost associated with the funds required to obtain the extra $84 \mathrm{AU}$ moderate stocking and the loss of cattle value associated with destocking due to drought in August 1994. We assigned a $7 \%$ interest fee to the $\$ 56,700$ value of the extra 84 AU under moderate stocking. This was the average amount of interest paid on 30 year U.S. treasury bonds in the 1991 through 1994 period. When this interest income $(\$ 3,969)$ was added to income of conservatively stocked pastures, average net return per ha for the 2-year period was $\$ 1.77$.

Mature cows were valued at $\$ 650$ per cow in the autumn of 1990 (Torell and Word 1991). Their liquidation value during drought in late summer 1994 was \$525 per cow. On this basis, the total loss in value associated with cattle liquidation in August 1994 was $\$ 25,000$ for a conservatively stocked ranch (200 AU) and $\$ 35,000$ for a moderately stocked ranch (284 AU)

Our decision to sell all cattle in late August 1994 was based on a variety of factors that included pasture stubble height levels, loss of cow weight and their poor body condition, historic climatic patterns, and the outlook for cattle prices. Stubble height for black grama averaged $5.2 \mathrm{~cm}$ in conservatively stocked pastures compared with $1.9 \mathrm{~cm}$ in moderately stocked pastures (Nelson et al. 1996). Mesa dropseed stubble heights averaged 9.6 and $4.2 \mathrm{~cm}$ in conservatively and moderately stocked pastures, respectively. These are below recommended minimum levels $(7.6 \mathrm{~cm}$ for black grama, $16 \mathrm{~cm}$ for mesa dropseed; Paulsen and Ares 1962). Historically dry years are clustered together in southwestern New Mexico (Paulsen and Ares 1962). As it turned out, our decision to destock was wise as total precipitation and growing season precipitation in 1995 were both less than $75 \%$ of the long term average. Cattle prices in the autumn of 1995 were 
$20 \%$ below those in 1994 . Our subsequent forage inventories in the 4 pastures in the autumn of 1995 showed forage production averaged 94 and $47 \mathrm{~kg} \mathrm{ha}^{-1}$ on conservative and moderately stocked pastures, respectively. This is less than one third the average for the previous 10 years. The financial analysis presented in Table 5 demonstrate the critical importance that calf crop percentage plays in ranching profitability. Other rangeland studies have consistently shown this same effect when supplemented feed inputs were minimized (Bentley and Talbert 1951, Houston and Woodward 1966, Lewis et al. 1956). We recognize that many ranchers who use moderate and heavy stocking rates use supplemental protein and energy to improve calf crop percentages. The average medium sized Chihuahuan Desert rancher in New Mexico in 1993 and 1994 spent about $\$ 32.79$ and $\$ 55.74$ per AU on protein and energy supplements while calf crops for these ranchers averaged $75 \%$ and 64\% in 1993 and 1994, respectively. Calf weaning weights averaged 187 and $210 \mathrm{~kg}$ in 1993 and 1994, respectively. In 1993, returns per $\mathrm{AU}$ and per ha were $\$ 64.44$ and $\$ 2.26$ compared to $\$ 11.06$ and $\$ 0.39$ in 1994 (Torell and Hawkes 1995, Torell et al. 1998). Relative to a hypothetical average rancher using supplemental feed and a moderate stocking rate, the conservatively stocked rancher would have made more money ( $\$ 1.77 /$ ha versus $\$ 1.44 /$ ha) for the 2-year period. Furthermore, the level of risk to drought and low cattle prices was much less than if a moderate stocking rate was applied.

One benefit we could not quantify due to the short time period in our study was stocking rate effects on grazing capacity. Other studies on arid rangelands in the southwestern United States have indicated that over a 10 - to 20 -year period conservative stocking will increase grazing capacity 15 to $30 \%$ over moderate stocking levels (Paulsen and Ares 1962, Martin and Cable 1974, Holechek et al. 1994). In semiarid areas, conservative to light stocking has increased grazing capacity 10-30\% over moderate stocking (Klipple and Bement 1961). After a comprehensive review of the literature, Van Poollen and Lacey (1979) found across all studies that herbage production was $28 \%$ higher under light versus moderate stocking. Residual perennial forage grasses must be present for conservative stocking to be an effective rangeland improvement tool (Klipple and Bement 1961). This criterion was met on our study pastures.

\section{Experimental Limitations}

We consider the short time period (1992-1994) involved in our study to be an important limitation. Several years (at least 10) are often required for stocking rates to have major impacts on rangeland vegetation (Klipple and Costello 1960, Smith 1967, Martin and Cable 1974). Because we used heifers in this study, the initial effects of stocking rate on cattle productivity may have been accentuated compared to mature cows. Young cattle are reproductively more sensitive to rangeland nutritional conditions than mature cows (Wallace 1987).

Our financial analysis supported observations by Martin (1975) and Holechek (1992) that even on a short term basis (2-5 years) conservative stocking is financially more effective than moderate stocking in desert environments. However, we acknowledge that under different climatic conditions, cattle prices, and ranching costs, the results could have been different.

\section{Management Implications}

These data provide evidence to suggest that Barzona, Beefinaster, and Brangus cattle are similarly suited to Chihuahuan Desert rangelands. Calf crop percentages were greatly affected by stocking rate averaging 20\% higher under conservative than moderate stocking for the 1993-1994 study period. Financial analyses support observations by Houston and Woodward (1966), Martin (1975) and Holechek (1992) that in arid and semi-arid environments conservative stocking provides similar or superior monetary returns to moderate stocking with less risk. Conservative stocking also has benefits of increasing grazing capacity on depleted rangelands with residual forage species (Klipple and Bement 1961, Paulsen and Ares 1962, Valentine 1970, Martin and Cable 1974, Polechek et al. 1994). The data herein provide indication that stocking desert rangelands for $35 \%$ use of key forage species as suggested by Paulsen and Ares (1962), Valentine (1970), Martin (1975), and Holechek (1992) is a sound practice from livestock production and financial standpoints. We recognize that our results have the limitation of a short time frame (1992-1994).

\section{Literature Cited}

Anderson, E. W. and W. F. Currier. 1973. Evaluating zones of utilization. J. Range Manage. 26:87-91.
Becerra, R. DeAlba, J. Winder, J. L. Holechek, and M. Cardenas. 1998. Diets of 3 cattle breeds on Chihuahuan Desert Rangeland. J. Range Manage. 51:270-275.

Bentley, J. R. and M. W. Talbot. 1951. Efficient use of annual plants on cattle ranges in the California foothills. USDA, Circ. 870.

Blanton, J. R., Jr. 1995. Range behavior of Brangus, Barzona, Beefmaster, and Hereford $x$ Angus cattle on semidesert rangelands. M.S. Thesis. New Mexico State Univ., Las Cruces, N.M.

Dyksterhuis, E. J. 1949. Condition and management of rangeland based on quantitative ecology. J. Range Manage. 2:104-115.

Herbel, C. H. and A. B. Nelson. 1966. Species preference on Hereford and Santa Gertrudis cattle on southern New Mexico range. J. Range Manage. 19:177-181.

Holechek, J. L. 1988. An approach for setting stocking rate. Rangelands 10:10-14.

Holechek, J. L. 1992. Financial benefits of range management in the Chihuahuan desert. Rangelands 14:279-284.

Holechek, J. L. 1994. Financial returns from different grazing management systems in New Mexico. Rangelands 16:237-240.

Holechek, J. L. and R. D. Pieper. 1992. Estimation of stocking rate on New Mexico rangelands. J. Soil and Water Conserv. 47:16-19.

Holechek, J. L., H. Gomez, F. Molinar, and D. Galt, 1999. Grazing Studies: What We've Learned. Rangelands 21(2)12-16

Holechek, J. L., A. Tembo, A. Daniel, M. J. Fusco, and M. Cardenas. 1994. Long-term influences on Chihuahuan Desert rangeland. Southw. Nat. 39:342-349.

Houston, W. R. and R. R. Woodward. 1966. Effects of stocking rates on range vegetation and beef cattle production in the northern Great Plains. USDA Tech. Bull. 1357.

Klipple, G. E. and R. E. Bement. 1961. Light stocking-Is it economically feasible as a range improvement tool? J. Range Manage. 14:57-62.

Klipple, G. E. and D. F. Costello. 1960. Vegetation and cattle responses to different intensities of grazing on shortgrass ranges of the central Great Plains. USDA Tech. Bull. 1216.

Lewis, J. K., G. M. Van Dyne, L. R. Albee, and $\mathbf{F}$. W. Whetzall. 1956. Intensity of grazing: Its effect on livestock and forage production. S. Dak. Agr. Exp. Sta. Bull. 459.

Martin, S. C. 1975. Stocking strategies and net cattle sales on semi-desert range. USDA. For. Serv. Res. Pap. RM-146.

Martin, S. C. and D. R. Cable. 1974. Managing semidesert grass-shrub ranges: Vegetation responses to precipitation, grazing, soil texture, and mesquite control. USDA Tech. Bull. 1480.

Nelson, T. 1996. Wildlife numbers on good and fair condition Chihuahuan Desert rangelands. M.S. Thesis. New Mexico State Univ., Las Cruces, N.M.

Nelson, T., J. L. Holechek, R. Valdez, and M. Cardenas. 1997. Wildlife numbers on late and mid seral Chihuahuan Desert rangelands. J. Range Manage. 50:593-599. 
New Mexico Department of Agriculture. 1994. New Mexico Agricultural Statistics.

Paulsen, H. A. and F. N. Ares. 1962. Grazing values and management of black grama and tobosa grasslands and associated shrub ranges of the southwest. USDA Tech. Bull. 1270.

Pieper, R. D. and C. H. Herbel. 1982. Herbage dynamics and primary productivity of a desert grassland ecosystem. New Mexico Agr. Exp. Sta. Bull. 695.

SAS. 1988. SAS/STAT User's Guide (Release 6.03). SAS Inst. Inc., Cary, N.C.

SCS. 1980. Soil survey of Dona Ana country, New Mexico. Soil Cons. Serv., USDA.

Smith, D. R. 1967. Effects of cattle grazing on a ponderosa pine-bunchgrass range in Colorado. USDA For. Serv. Tech. Bull. 1371.

Steel, R. G. and J. H. Torrie. 1980. Principles and procedures of statistics. McGraw-Hill Book Co., N.Y.
Torell, L. A. and J. H. Hawkes. 1995. Range livestock cost and return estimates for New Mexico, 1993. New Mexico Agr. Exp. Sta. Res. Rep.

Torell, L. A., J. M. Hawkes, and . T. D. Stromer. 1998. Range livestock cost and return estimates for New Mexico, 1994. New Mexico Agr. Exp. Sta. Res. Rep. 724.

Valentine, K. A. 1970. Influence of grazing intensity on improvement of deteriorated black grama range. New Mexico Agr. Exp. Sta. Bull. 553.

Vallentine, J. F. 1990. Grazing management. Academic Press, Inc., N.Y.

Van Poollen, H. W. and J. R. Lacey. 1979. Herbage response to grazing systems and stocking intensities. J. Range Manage. 32:250-253.

Vavra, M., R. W. Rice, and R. E. Bement. 1973. Chemical composition of the diet, intake, and gain of yearling cattle under different grazing intensities. J. Anim. Sci. 36:411-414.
Wallace, J. D. 1987. Supplemental feeding options to improve livestock efficiency on rangelands. In: Achieving efficient use of rangeland resources. Fort Keough Res. Symp. Montana Agr. Exp. Sta., Bozeman, Mont.

Winder, J. A., B. J. Rankin, and C. C. Bailey. 1992. Maternal performance of Hereford, Brangus, and reciprocal crossbred cows under semidesert conditions. J. Anim. Sci. 70:1032.

Winder, J. A., D. A. Walker, and C. C. Bailey. 1996. Effect of breed on botanical composition of cattle diets on Chihuahuan Desert. J. Range Manage. 49:209-214.

Wood, J. E. 1969. Rodent population and their impact on desert rangelands. New Mexico State University Agr. Exp. Sta. Bull. 555. 